\title{
Democracy and Local Election in Indonesian: Case Study of Local Leaders Election at Depok
}

\author{
Tukina \\ Marketing Communication Department, Faculty of Economic \\ and Communication \\ Bina Nusantara University \\ Jakarta, Indonesia \\ awasita@yahoo.com
}

\author{
Agus Wasita \\ Marketing Communication Department, Faculty of Economic \\ and Communication \\ Bina Nusantara University \\ Jakarta, Indonesia
}

\begin{abstract}
The election of Mayor and Deputy in Depok in 2015 is a means of democratization in local. In the election, the aspirations of the citizens are free according to their wishes and expectations. This study seeks to examine the problems that arise in the selection of Mayor and Deputy, then must also look for solutions. The research was carried out with a descriptive qualitative methodology. Data obtained in the field and then exposed to inductive analysis through the planned stages. To support the research action was taken; observation, find and find key informants, and then in-depth interviews. Depok residents live side by side with cities (urban areas) and in general activities and work in Jakarta so that there are obstacles in data collection voters. For problems during and after the election can be solved because there is good coordination. Legal issues related to elections can be reduced because the initial General Election Commission Depok has socialized broad rules and sanctions with consequences. Rules made by the Government need to be properly socialized and sufficient time. The Government (State) needs to think of new ways of local elections, especially for urban cities, e-vote.
\end{abstract}

Keywords-Democracy, Local Election, Local Leaders Election, Depok

\section{INTRODUCTION}

General Election is the basic prerequisite of Democracy in Indonesia. General Election is needed in the context of how the people's voice is periodically channeled through a 5-year mechanism in an institutionalized and peaceful manner. With a good general election, giving citizens wide freedom. Though election citizens determine the direction, government policies and also choosing leaders to sit in political representation institutions and also choosing Indonesian government officials. For and within that framework, a good and quality election is needed.

General elections are the basic means of how people's voices are channeled. The more citizens have freedom, the aspirations will be channeled and vice versa. Freedom of speech is in order to get the accuracy or correctness of the voice of people's hope not to be misused. A sincere voter is one who only chooses the party they like most regardless of the consequences. Sincere voters (loyal voters) do not care about election results, seat allocation, and government formation. Strategic voters are citizens who vote for a less preferred party choice, to influence the outcome of the election or the formation of the government (Willocq, 2016)
Ideally, the truth of choice in accordance with the aspirations of citizens will be achieved when there is freedom in determining political choices. Such conditions are also influenced by Social Media. The effect of social media in that activities have broad effects, including making information, public education about the legal process, the creation of collective knowledge, transparency and public order in society. The role of critical social media in the general political landscape of campaigns, demonstrations, elections, is an important part of the Election (Atengble, 2014)

Freedom in voting is very important. Without political freedom, it is difficult to hope that the election will produce things that are in line with the expectations and aspirations of citizens, in other words, the election products will be further away from the aspirations and hopes of citizens. The impact of elections that are not qualified (run badly) will result in members of political representation, political leaders and also the rules produced are not of a quality.

Quality elections are very important and fundamental, including in this case the Regional Head General Election. In the election process at different levels, Local Government or Parliamentary elections. With an increase in the level of election, the direct role of elected representatives in local affairs is reduced. Representatives are more involved with broader policy-making and governance issues that tend to influence larger populations in several locations (Diganta Mukherjee, Rajlakshmi Mallik, 2012).

Local elections mayor and deputy need to be maintained and always directed to good quality things so that the people's voice is well channeled. In channeling the voice there needs to be free. Freedom in channeling votes needs to be obedient and subject to rules and not to be misused, it needs a clear corridor of how political freedom is channeled and safeguarded. The term is also maintained in the sense that the corridors of freedom do not deviate from the existing political paths and mechanisms.

The selection of the Mayor and Deputy Mayor of Depok is part of the Election at the Local level. The Regional Head Election (Regiant Election Depok) for the first time was held simultaneously with several other regions in Indonesia nationally. This research is interesting because the election of the Mayor and Deputy Mayor simultaneously was carried out for the first time. This study focused on the Implementation of the Election of Mayor and Mayor of Depok in 2015 and uncovered problems related to the Organization and sought solutions to the problem. 


\section{METHODOLOGY}

This research is descriptive qualitative research. Data is collected through the growth process. The research literature is carried out until the data is sufficient to explain clearly the subject matter. Observation journals are carried out as research techniques, which are the main roles in qualitative research. The approach used is a qualitative method. The approach aims to explain deep phenomena through data collection. A qualitative approach to certain traditions in social science which basically depends on observation in humans, both in the region and in its terminology. Bogdan and Taylor (1975) define qualitative methodology as a research procedure that produces descriptive data in the form of written or oral words from people and observable behavior.

Data used in research; Primary Data, in form; obtained through in-depth observation with specific targets, in-depth interviews using interview guidelines (structured) that were prepared before key informants. Secondary data; obtained through research that has been done, search for research journals, books, papers, newspapers, and searching for information via the internet (browser).

Field qualitative data will be analyzed inductively based on the stated research objectives. In qualitative research, data analysis is a very important part because of this analysis the results of the research will be obtained. Qualitative data analysis does not run linearly, and no systematic rules that are the main target are the objectives of the study itself.

Researchers collect data, sort data based on research objectives. Data is focused on answering research objectives. Through the analysis process, meaningful and meaningful information will be obtained. To get meaningful and meaningful data, a deep understanding is needed. To achieve a deep level of understanding and understanding, a researcher must possess intelligence, creativity, conceptual sensitivity, a certain experience, and expertise.

How to test the credibility of the data or trust is done by expanding observation, increasing persistence in research, triangulation, peer discussions, negative case analysis, and member checks. While the triangulation method to measure the level of validity. The triangulation method is an attempt at 'measurement' which is done by comparing results.

\section{RESULTS AND DISCUSSION}

\section{A. Political Conditions in General Depok City}

Depok residents are divided into citizens who have voting rights and not. Residents who have voting rights are also divided by sex, male and female. Polling Station (TPS) are spread throughout Depok City. The election of Local Leaders is carried out on a Package (candidate pair). Candidates who will advance will need to be widely socialized.

The election of Local Leaders Depok was proposed by the General Election Commission of Depok (Indonesia=KPU Depok). General Election Commission Depok is filled by 5 Commissioners and one chairman is elected. General Election Commission Depok works on the basis of supervision as Hierarchy is under the General Election Commission Province and National General Election Commission. General Election Commision Depok is selected in a certain period of 5 years.
The General Election Commission Depok only tried to propose to become a state official but had not succeeded. The way the General Election Commission works is permanent from the Depok Regional Election Organizer, after that the Governor Election preparation and also the Presidential Election. Besides General Election Commission, there is a Depok Election Supervisory Agency, Depok City Election Supervisory Committee (Panwaslu Depok). The Supervisory Commiittee is ad-hoc formed within a certain period after it is disbanded, its nature is not permanent. To expedite the Election there is also the Supervisory Commiittee (KPPS), and Chair of the polling stations (KTPS). Besides that, it was also secured by Community Security Officers, Police, and military.

In the Mayor of Depok Election in 2015, the total population of Depok City was 1,962,160, the number of polling stations (Iindonesia=Tempat Pemungutan Suara/TPS): 3,235 , the number of male voters: 608,468 , the number of female voters: 613,624 , the total list of permanent voters in Depok: 1,222,092. The selection of Depok Mayor and deputy mayor was followed by 2 candidate pairs (Package system) as follows:

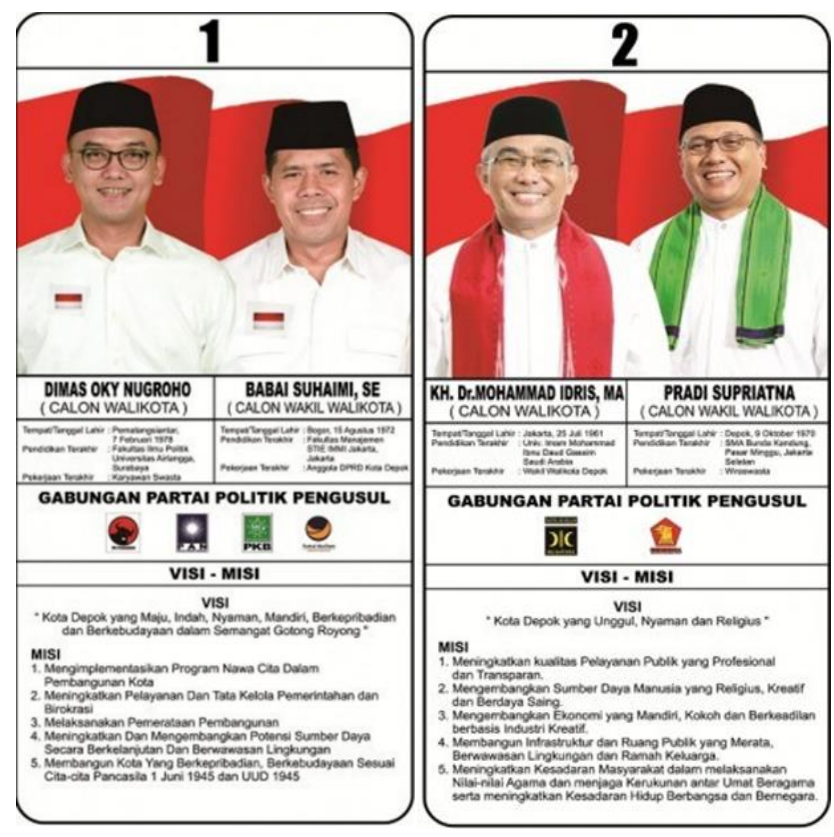

Table 1. Obtaining Candidate Pair Votes

\begin{tabular}{|c|c|c|c|}
\hline Candidate & Party & Vote & $\%$ \\
\hline $\begin{array}{c}\text { 1. Dimas Oky } \\
\text { Nugroho } \\
\text { Babai Suhaimi }\end{array}$ & $\begin{array}{c}\text { PDIP, PAN, } \\
\text { PKB, Nasdem }\end{array}$ & 253.086 & $38,09 \%$ \\
\hline $\begin{array}{c}\text { 2. Idris Abdul } \\
\text { Shomad } \\
\text { Pradi Supriatna }\end{array}$ & $\begin{array}{c}\text { PKS, } \\
\text { Gerindra }\end{array}$ & 411.367 & $61,91 \%$ \\
\hline \multicolumn{2}{|c|}{ Not valid, abstentions } & 557.576 & $100 \%$ \\
\hline \multicolumn{2}{|c|}{ Total Vote } & 664.453 & \\
\hline \multicolumn{2}{|c|}{ Registered Voters } & 9 & \\
\hline
\end{tabular}




\section{Resource: Wikipedia Pemilihan Walikota Depok}

\section{B. Preparing for the Election of the Mayor Depok}

The preparation of the Depok Regional Election which was held simultaneously nationally is indeed not yet mature. Especially related to budgets and laws that change. The Mayor's term of office ended in mid-June 2016, many strategic policies could not be carried out in the Depok Mayor's Task Force (Indonesia =Pelaksana Tugas/PLT) discourse. This is the basis of consideration to be advanced and must take part in the elections (simultaneously) in 2015. It should be that simultaneous elections will be held in 2017, meaning that the Mayor's term of office is reduced by one month but the inauguration remains in January. Of course, this requires coordination between General Election Commision and Depok City Government.

In the ranks of the Depok City DPRD itself, a meeting was held to decide the sustainability of Depok City Election, which was realized or not it had cut the one-month term of the mayor of Depok City before. The reason is because of the many strategic policies that were not implemented. Here is also shown a sudden change in regulation. That is, the City of Depok no longer participates in the elections simultaneously in 2017 based on the decision of the Depok City DPRD.

General Election Commission Depok proposes the budget for the Election of Regional Heads, in fact, from the budget proposed by the General Election Commission of 49 billion, Depok City Government only provides 37 billion. In the end, Depok City Government only added seven billion of the budget in October. That problems to be able to run need an adequate budget. Money is one of the important factors in procurement, let alone the elections, and suddenly the proclaimed budget does not come out with the same number. This is what troubles the General Election Commission team. The remaining budget that is not disbursed by the Depok City Government is five billion. The numbers are quite spectacular. In this case, it was also questioned whether the budget preparation did not follow the law, the previous Depok City Election, and the Depok City Election procurement research if it was conducted in 2015; or indeed there is a suspicion of budget delinquency because there is no further explanation.

Institutionally, General Election Commission Depok is indeed required to be ready for the election. Implementation needs to be based on law. Initially, the General Election Commission Depok carried out the implementation based on Law No. 1 / Th.2015. Initially, Depok City was not included in the region that held Simultaneous Local Elections, but because the term of office of the Mayor ended, it was close to 2015. So, it had to be drawn into 2015.

A far more serious obstacle, simultaneous regional elections that should be held in 2017, whose budget allocation has also been stipulated in Law No. 8 Ratification of Substitute of Law/ Government Regulation In Lieu of Law (Indonesia=Peraturan Pemerintah Pengganti Undangundang/Perpu) No. 1/2015 should be held in 2017. However, there is a change in Law No. 10, so that the simultaneous election was held in 2015. Hence, in a very narrow time, preparation must be ripe with a budget that is not fully provided. This statement becomes another expression, that a sudden change in the Law, let alone be implemented in the near future, will certainly invite many problems. No matter how often the Depok City Election takes place, it involves the dignity of the lives of the people of Depok City during the five-year term of office, also concerning policy issues, whether it is indeed practical in changing the law. Sudden changes, even causing unpreparedness in implementation and preparation, can certainly be a challenge. Tragically, this unique Depok City Election can be an example for other cities that hold similar elections.

The implementation of the elections is not just an ordinary matter, this is related to the way the Government is to protect citizens. In fact, the difficulties in preparing for the 2015 elections are related to regulations that are too long established and without screening or research. The 2015 Regiant Election preparations were exacerbated due to hasty decision making and were immediately stipulated in the law. It is conceivable, decisions were swayed throughout 2014, and set early in 2015 , and must also be implemented in 2015, a very short time. This has become a challenge for the Depok City Election in 2015.

In general, the Depok elections run normally, and preparations have indeed been done carefully with the time available. Before the Election of the head of Depok City was held, the Depok City, General Election Commissions Depok coordinated with the government. In addition to the budget, General Election Commission Depok also compiled rules regarding the technical implementation of the Depok Mayor. The General Election Commission Depok is ready to carry out the Election because the Regional Election is not the first time held. General Election Commission has experience in carrying out the General Election of Mayor. This statement can be viewed as an optimistic attitude or expressed to hide the truth about the initial problems that arose earlier. In addition, the preparation of Depok City Election is more technical. According to him, the preparations carried out included coordinating with relevant institutions and agencies, making budgets, making phases of activities, creating work activities, forming PPK and PPS. This procedure itself must indeed be known by the General Election Commission, as a form of carrying out its duties and responsibilities to organize Depok City Election. The entire series of preparations for the Depok City Election, there were problems. These problems include hasty and inaccurate decision making in the enactment of laws that result in little time availability, as well as a budget that is insufficient for the implementation. Even though it seems that the Depok City Election has become a regular routine. In an election the citizens may not be aware of seems to be a problem, but it still needs special attention. Moreover, from these relatively regular activities (according to the mayor's term of office), it still does not have provisions in valid laws.

\section{Problems in Organizing Depok Election}

\section{1) Problems in Organizing Before Mayor Election}

Depok elections are an important venue for every citizen, to choose a good leader. The General Election Commission commissioner struggled to prepare everything, starting from the adjustment of the law, budget, making procedures for activities, forming PPK and PPS, including Temporary Votter/Selector List and Fixed Votter/Selector List, setting the date of registration of candidates, health tests of candidate pairs, dissemination of activities, up to the election of elections and announcement of the results of the vote count.

During this process also some obstacles arise at certain points. The initial problem that arises is a very short time in 
preparation, as well as legislation that often changes. Other problems that arise when data collection on citizens who have voting rights are also problematic because most Depok City residents work in Jakarta. In the preparation of the Temporary Voter List (TVL) and the Permanent Voter List (PVL), Voter Data Update Officers experience obstacles. Difficulties that occur especially related to Data Collection (Depok ID card) residents who leave at dawn and go home at night (outside the election committee's working hours) there are even those who often leave the City, out of the country and some even rarely go home.

The implementation of the Depok City election has not been set as a National Holidays, and Depok Election falls on Wednesday, as a result, many people prefer to work (in Jakarta) rather than use their voting rights. This is precisely what causes the number of participating voters to only $56 \%$ of the total voters. Related to the issue during the Regiant Election there were also, especially from prospective candidates who could not participate as Depok mayor candidates. The cause of this prospective candidate could not be a candidate for mayor in the election was threatened because of the problem of the mechanism, procedures, and conditions for the nomination.

Election Organizations such as Election Oversight Committee (Indonesia=Panwaslu), Voting Organizers Group (VOG, Indonesia=KPPS), and TPS members are Ad hoc (not permanent/permanent). Organizers such as KPPS and TPS Members may only become organizers for a maximum of two periods. After two periods, the General Election Organizer is no longer allowed to be the Election Committee. On the other hand, people who have twice become Election Managers are actually trained people and have experience. With these rules, it is a new challenge because all this time the Organizing Committee is usually the person. The selection process of the Election Organizing Committee must be newly selected, openly looking for new people through the proposed subdistrict and village heads.

There were several obstacles before the Depok Regional Election took place. First, it is still related to the law, the limited implementation time and budget constraints. Another phenomenon that arises is the difficulty of officers in collecting data on voters who have voting rights. Participants in the election require voter registration, determination of polling stations, and attendance requirements, all of which require identification and data collection of the place of voice (Jesse T. Richman; 2014).

There are some residents of Depok City who tend to be apathetic about the election, the wheels of government. It could be due to administrative experience, the absence of meaningful change in Depok City, or indeed because of the level of priority in carrying out life. This statement shows the situation and existence of Depok City. Most Depok City residents work in Jakarta to continue their lives. This means that the development has not been maximized so that the work lands have not been able to absorb high numbers of labor to produce local products of Depok City that are competitive. Or the absence of a company that absorbs a large number of workers at an appropriate wage. This fact makes the citizens of Depok City have to choose to go to Jakarta, making a living as a priority for their lives. Logically, when casting a candidate for mayor does not know the person directly, only 'get acquainted' during the campaign. After being elected there is also no change, let alone to 'feed'.

\section{2) Problems of Organizing During/Moment of Local} Election

When the Depok election will take place, right on the polling day the two pairs of candidates who have passed the selection of candidates. Even with relatively short preparation. On December 9, 2015, the distribution of ballot papers was safe and smooth and there were no repeated voting. General Election Commission relied on KPPS to invite and remind residents directly to come to the polling station, in the pulpit and give circulars in the church.

At the time of the polling station, many parties were involved to secure the purity of the people's voice. General Election Commission anticipates data manipulation by means of $\mathrm{C} 1$ transparency, there is also monitoring of the place, as well as the role of NGOs that propose to create complaints posts. Coupled with Election Oversight Comiitte Regiant, Sub Regiat and Field Voter Committee (FVC).

General Election Commission Depok also embraced Heads of community, made announcements with loudspeakers, even around the city in a train car and coordinated with the police, election supervisors, and many other parties. In the 2015 election, no campaign was found that gave money/goods. The candidate pair has placed witnesses at KPPS / TPS. So, it can be ascertained that there is no significant fraud during the Depok Regional Election. To attract the attention of citizens to come to vote, some polling stations carried out special activities, such as competitions which were followed by socialization.

There are so many attempts by General Election Commission Depok to attract the attention of citizens to come to the polling station and use their voting rights. In principle, the idea of holding a race during the election for the sake of socializing the importance of the voice of each person in the elections. But their needs and interests are short-term. that is to say, the existence of the race will be the main object to do, not the election. In addition, for the time to come, residents will be waiting for the election because they want just the competition. It is true, the Election is a party of the people to elect new regional leaders. But this will be wrong, when the next Depok City Election does not hold a race, the level of citizen apathy towards political participation will actually increase.

Depok Election despite being smooth, other problems that occur, can be said to be sourced from the voters themselves. General Election Commission found an error in the polling station, polling station number, Polling station address by voters. Voters come using a different ID card, or one of the TPS. Indeed, in the process of educating citizens regarding election procedures is not an easy matter. There are behaviors that are problematic. Regarding the phenomenon of this field, shows that some residents still do not fully understand the procedure to vote at the polling station, where they are registered. In general, citizens only know to come to TPS, whichever is free. Then, take the ballot paper, mix it, finish, go home. Of course, such a mindset must be changed, an instant mindset that causes the disorder. Because of these mistakes, of course, citizens who have come to one polling station, if asked to go to the actual polling station, will lead to other attitudes, for example canceling to vote because they 
have spent transportation, labor and time. Equally, citizens become unconcerned (apathetic) with Depok City Election. In the end, this action contributed to increasing the percentage of Depok residents who were abstentions.

Furthermore, there was a mistake because of carrying an identity card (ID card), as a technical error, and in fact, every citizen did have more than one identity. That is, when taking care of certain administrations it does occur. At certain agencies with an A identity, in other agencies with identities $\mathrm{B}, \mathrm{C}$, and so on. The data error rate is very high if one person has more than one identity. This problem will cause other problems that are more serious. Among them, the validity and accountability of Depok City population data collection are problematic. Change clothes, change identity. One person can have two or more voting rights. If used in one pair of the same mayor candidates, it will certainly cause injustice. If used for each candidate for mayor the same, the voice becomes biased. If you don't vote at all, it will certainly trigger the high abstention rate in Depok City.

During the Election Regiant there were two lawsuits made by the General Election Commission that were submitted to the Administrative Court (AC) regarding General Election Commission rules. This problem is related to the alleged dispute over the election results of the mayor of Depok City. Coupled with the problems of prospective candidates who still have not accepted the fact that he was not accepted as a candidate for mayor in Depok City Election. Even though the prospective candidates were killed because they did not meet the requirements requested by the General Election Commission.

Another problem is about campaign props. Part of the campaign material submitted to the General Election Commission, the procurement made complicated the work of the General Election Commission. That is, the Campaign Props (Tools of Campaign) are not equipped with the installation procedure or position, so the General Election Commision has difficulty when installing a Campaign Props in the form of banners or billboards.

\section{3) Problems in Implementing After Depok Election}

The end of the/after voting process does not indicate that the problem is over, but still criticizing statements arise. One of them related to the tilted issue that still exists, for example, the issue of Tribe, Religion, Race and Intergroup, to the issue of primordial. Although only a handful, fortunately, it does not become a big and radical issue. Indeed, from the posters of the two pairs of candidates for the mayor advancing the use of the cap and religious attributes. In the poster, the party behind each candidate is different. One is supported by four parties, and one is only supported by two parties. The good thing is, administratively, the counting of votes is also conducive. Until the results came out, the most votes were paired with number two, namely Idris Abdul Shomad and Pradi Supriatna. The pair is supported by Prosperous Justice Party (Indonesia=Partai Keadilan Sejahtera/PKS) and Great Indonesian Movement Party (Indonesia=Partai Gerakan Indonesia Raya/Gerindra) political parties with 411,367 votes or $61.91 \%$.

Related to the lawsuit filed against the General Election Commission, namely the issue of holding elections there were election disputes that were tried to the Constitutional Court, including the candidate's claim to the Administrative Court. A lawsuit against the General Election Commission regarding the requirements of prospective candidates who did not meet the requirements was also revoked. General Election Commission fought hard in completing every turmoil that arose during the Depok City Election. Another serious problem that arises is that the number of people who do not use their voices is quite large, more than $40 \%$. Even though the votes collected still meet the quota of the election requirements, this abstention number needs to be further investigated.

Assuming people who do not use their voting rights because the residents are unable to attend (have to work in Jakarta), or because middle to upper-class citizens who are difficult to reach during socialization and constituents do not have candidates in accordance with their wishes, no candidates will be chosen. Especially for Depok City, the previous Election also experienced the same thing. Is there really no renewal of population data, because it is possible that residents who are suspected of not being in a place have indeed moved and vacated their property in Depok, or only limited to work in Jakarta. Indeed, the General Election Commission has tried to attract the attention and interest of the citizens of Depok City in various ways. However, these conventional methods are not only ineffective, but create an impression for some circles as an event to 'spend' the budget of Depok City Election. For the upper class who are not affordable by the General Election Commission Depok, they have a different mindset from other citizens who can still be driven by the race.

For middle and upper citizens, holding the principle that every change of leadership there will only be changes in the administrative system which makes it easier or more difficult for the previous administration period. They are more vigilant to anticipate this, compared to being actively involved in the politics of Depok City Election. The limited time owned by the upper middle class is also the same as the General Election Commission which has to prepare for the Depok City Election in 2015. Their priority tends to family welfare without political excuses. Even though they have free time, they will certainly prefer to be with family compared to TPS to use their voice. Because they have not felt a significant change in the change of regional leaders.

There are also other factors that can cause this, namely political chaos in Jakarta. Many Depok residents who work in Jakarta, could be due to the power of the mass media which more often exposes the lifestyle and political behavior that occurs in Jakarta, so that Depok residents are blind to the political conditions in Depok itself. It is undeniable, many parties are actually directly involved and active in government in DKI Jakarta. The incessant electronic mass media and social media are the main weapons for many layers of citizens towards the way of Government. Therefore, it is also important to shift conventional ways into digital ways to attract the interest and attention of citizens, especially Depok residents.

\section{CONCLUSION}

Based on previous discussion, this paper suggest some solution to the issue of organizing depok local election. Need to do analysis or research before making changes to the law. Moreover, immediately implemented in the near future, of course, it will cause mistakes. If you wish to make 
amendments to the law, it is necessary to review the timing of the law stipulation with the period of implementation of the law. That is, there must be sufficient time to make preparations that are in accordance with the new laws that are stipulated. The stipulated budget must adjust to each other and follow the prevailing laws and regulations. The inaccuracy of the determination and use of the budget will certainly cause a very crucial problem. The conditions for nominating regional heads from prospective candidates must be validated. In this case, everyone who will indeed advance in any election must be prepared mentally and physically. Procedures and requirements for the campaign Tools/Props (Indonesia= Alat Peraga Kampanye/APK) are included so that the General Election Commission Depok not experience difficulties from this kind of thing. Because there are other more important issues to solve.

Furthermore, utilizing data sources from e-ID Card to get more accurate data. The issue of citizen misunderstanding needs a more practical approach, so it is more effective. More sophisticated technology, such as social media. The design of socialization must also be interesting, especially to reach the upper middle class. Opportunities for Opportunities for Voting for Certain Areas such as Urban Adapted to Technological Development. To realize the elections, especially the quality of Depok City Election requires an understanding rules. The political party knows of the Main Tasks and Functions right so as not to violate the rules, or overlapping duties and responsibilities. More intensive coordination is needed for the Depok government and related stakeholders.

\section{REFERENCES}

[1] Atengble Kirchuffs Social Media and Ghana's 2012 Election [Journal]. - Institute for Scientific and Technological Information (CSIR-INSTI), Accra, Ghana: Copyright $\odot 2014$ by author and Scientific Research Publishing Inc., 2014. - Vol. 2. - pp. 121-126.

[2] Diganta Mukherjee, Rajlakshmi Mallik Education and Electoral Outcomes [Journal] // Theoretical Economics Letters. - Kolkata, India : [s.n.], February 15, 2012. - Vol. 2. - pp. 186-191.

[3] Jesse T. Richman, Guslan A. Chattha, David C. Earnest Do NonCitizen Vote in U.S. Election? [Journal]. - George Mason USA : [s.n.], 2014. - http: //dx.doi.org /10.1016/j.electstud.2014.09.001 : Vol. 36.

[4] Willocq Simon Why Do Voters Change Their Mind during an Election Campaign? An Analysis of the Determinants of Campaign Volatility at the 2014 Belgian Federal Elections [Journal]. - CEVIPOL, Université libre de Bruxelles, Brussels, Belgium : Copyright @ 2016 by author and Scientific Research Publishing Inc., 2016. - 04 : Vol. 06.

[5] Creswell. John W. (2010). Research design; Pendekatan kualitatif, kuantitatif dan mixed. Yogyakarta.Pustaka Pelajar.

[6] Sadini, Nur Hidayat (2014). Kepemimpinan Pengawasan Pemilu, sebuah Sketsa. Jakarta : RajaGrafindo Persada

[7] UU No.32 Tahun 2004: Undang-undang tentang P3emerintahan Daerah

[8] UU No. 23 Tahun 2014 : Undang-undang tentang Pemerintahan Daerah

[9] Accessed Saturday 1, October 2016, resource: www.General Election Commissionsdepokkota.go.id

[10] Accessed Monday 3, October 2016, sumber: http://en.wikipedia.org/wiki/stateof Art. Definisi state of the art. 